\title{
FORENSIK BIOLOGI DALAM PENJAGAAN NASAB (HIFZ AL-NASAB / NASL)
}

Ahmad Syukran Baharuddin ${ }^{1}$, Mohamad Amir Wan Harun ${ }^{1}$, Aminuddin Ruskam ${ }^{1}$, dan Abdul Rahim Yacob ${ }^{2}$

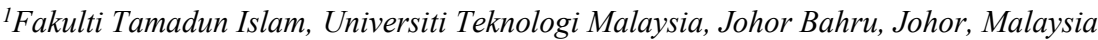

${ }^{2}$ Fakulti Sains, Universiti Teknologi Malaysia, Johor Bahru, Johor, Malaysia

*Corresponding author: ahmadsyukran.baharuddin@gmail.com

Article history

Received: 16/11/2014

Received in revised form:7/2/2015

Accepted:11/02/2015

\begin{abstract}
Maqasid al-Shari'ah focusses on each of the elements in al-Daruriyyāt, followed by al-Hajiyyat and al-Tahsiniyyāt. Among the main topics in the discussion of al-Daruriyyāt is Hifz al-Nasl/ Nasb which is the preservation of ancestry. It is admitted that forensic science provides a consistent role in human life. However, only few know the success of forensic science in solving great significance cases in determining the lineage that led to one of the key elements of al-Daruriyyāt in Maqasid al-Shari'ah. Therefore, this study aimed at investigating the role of forensic science in determining the heredity. This study has the objective to analyze the classic texts which contain elements of forensic science that led to the determination of lineage, to review the appropriate techniques in determining heredity and analyse relevant cases in determination of heredity proven by forensic science. Method used is this study were historical, inductive and deductive. Scope of the study were the determination of heredity through physical trait analysis and serology (blood) in cases which are not related to Islamic criminal jurisprudence. This study concluded that the forensic biology is an accurate method in preserving heredity and it is in line with the Islamic legal maxims.
\end{abstract}

Keywords:

\begin{abstract}
Abstrak
Maqāsid al-Shari'ah memberi penekanan kepada setiap unsur-unsur dalam al-Daruriyyāt , diikuti dengan al-Hajiyyāt dan juga al-Tahsiniyyāt. Antara yang menjadi topik utama dalam perbincangan mengenai al-Daruriyyāt adalah Hifz al-Nasl/nasb iaitu penjagaan keturunan. Dunia mengakui bahawa sains forensik memberi peranan yang konsisten dalam kehidupan manusia. Namun tidak ramai mengetahui bahawa keberhasilan sains forensik menyelesaikan kes mempunyai signifikan yang besar kepada penentuan keturunan yang membawa kepada salah satu dari elemen penting dalam al-Daruriyyāt dalam Maqāsid al-Shari'ah. Oleh itu, kajian ini bertujuan untuk mengkaji peranan sains forensik dalam menentukan nasab. Kajian ini juga mempunyai objektif untuk menganalisis teks klasik yang mempunyai elemen sains forensik yang membawa kepada penentuan nasab, mengkaji teknik bersesuaian untuk menentukan nasab dan menganalisis kes berkaitan penentuan nasab yang dibuktikan melalui sains forensik. Metod yang digunakan adalah analisis secara historis, induktif dan deduktif. Limitasi kajian adalah kepada penentuan nasab melalui analisis trait fizikal dan serologi darah dalam kes yang tidak berkaitan dengan fiqh jenayah. Hasil kajian mendapati bahawa forensik biologi merupakan suatu ketepatan dalam menjaga nasab dan tertakluk kepada kaedahkaedah fiqh.
\end{abstract}

Kata kunci: Serologi darah, Hifz al-Nasl/nasb, al-Qiyafah, al-Qarinah, Trait Fizikal, forensik biologi 


\subsection{PENGENALAN}

Kemajuan teknologi masa kini memberi impak yang besar kepada evolusi ketamadunan manusia. Pengaruh teknologi dalam kehidupan harian manusia hingga kini tidak dapat dinafikan telah memudahkan urusan manusia dan membuatkan ianya menjadi lebih efisyen seterusnya menjadikan segala kemungkinan menjadi realiti. Sepertimana manusia yang perlu kepada teknologi, begitu juga dunia yang sangat memerlukan teknologi untuk menambahbaik elemen teras bagi kehidupan. Sains forensik sebagai contoh, adalah salah satu cabang daripada bidang sains dan teknologi yang mengalami evolusi yang sangat pantas. Umum mengetahui bahawa sains forensik meliputi pelbagai bidang, dalam konteks perbincangan ini, sains forensik difokuskan kepada penghakiman kes yang berkaitan nasab. Namun, tidak ramai yang mengetahui bahawa sains forensik mempunyai peranan yang besar dalam merealisasikan Maqāsid alShari'ah. Maqāsid al-Shari'ah secara umumnya berkisar kepada menjaga kemaslahatan masyarakat dan individu, dan ianya bertujuan untuk menjaga dan memelihara kemaslahatan ini seterusnya menyumbang kepada suatu suasana kondusif dalam kehidupan manusia untuk mengabdikan diri kepada Allah (alSulami, 1991). Maqāsid al-Shari'ah adalah suatu ilmu yang membincangkan mengenai objektif dan tujuan bagi suruhan yang telah Allah aturkan berdasarkan dalil-dalil syar'ie yang mu'tabar (al-Shātịīi, 1997).

Hal ini secara tidak langsung telah membuka dimensi kepada perbincangan yang meliputi ruangruang yang berkaitan dengan penjagaan beberapa elemen asas kepada manusia iaitu penjagaan agama, nyawa, 'aql, keturunan dan harta (al-Raysuni, 2006; Auda, 2010). Dengan kemajuan perkembangan teknologi dan kewujudan metod baru dalam sains forensik, ianya telah menambahbaik ketepatan dan meningkatkan kejituan bagi sesuatu ujian dalam sains forensik (Paola A. Prada, B.S., \& Furton, 2008; Thomas, 2003). Persoalannya adalah bagaimana bidang sains forensik ini boleh memberi peranan kepada Maqāsid al-Shari'ah terutama dalam penjagaan nasab? Adakah terdapat bukti yang menunjukkan bahawa ianya diterima dalam Islam? Sejauh mana ianya digunakan pada masa kini meliputi kes-kes yang berkaitan penentuan nasab? Oleh itu, kajian ini bertujuan untuk menyingkap dan menjawab persoalanpersoalan tersebut.

\subsection{KEPENTINGAN NASAB DALAM ISLAM DAN KAEDAH PENSABITANNYA}

Sejarah Islam telah membuktikan bahawa nasab merupakan sesuatu yang amat penting dalam Islam sehinggakan terdapat ayat al-Qur'an yang khusus mengisyaratkan kepada penjagaan nasab. Ayat dari Surah al-Ahzab ayat empat hingga lima memberi garis panduan kepada proses memberi nasab kepada anak-anak kandung dan juga anak angkat (Ibn Kathir, 1999). Nasab secara literal bermaksud nisbah kepada sesuatu dan dari sudut epistemologi fiqh ianya dijelaskan sebagai al-Qarābah iaitu sambungan antara dua manusia dengan persamaan dari sudut kelahiran sama ada jauh atau pun dekat (al-Jurjani, 1983; Al-Mawsū'ah al-Fiqhiyyah al-Kuwaytiyyah, 1995; Ibn Manzur, 1994). Seperti dalam surah alAhzab ayat 5 Allah s.w.t berfirman:

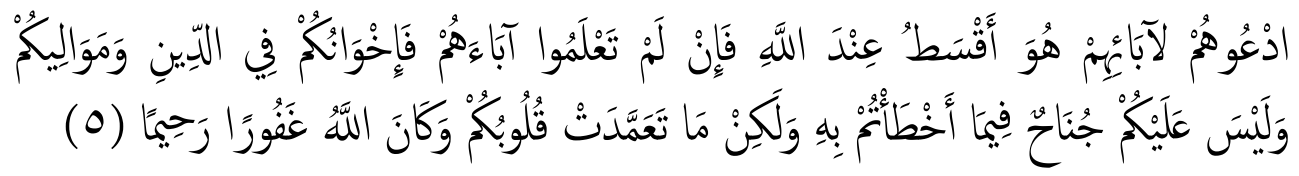

Ertinya: Panggillah anak-anak angkat itu dengan ber'bin'kan kepada bapa-bapa mereka sendiri; cara itulah yang lebih adil di sisi Allah. Dalam pada itu, jika kamu tidak mengetahui bapa-bapa mereka, maka panggillah mereka sebagai saudara-saudara kamu yang seagama dan sebagai "maula-maula" kaтu. Dan kamu pula tidak dikira berdosa dalam perkara yang kamu tersilap melakukannya, tetapi (yang dikira berdosa itu ialah perbuatan) yang disengajakan oleh hati kamu melakukannya. Dan (ingatlah Allah Maha Pengampun, lagi Maha Mengasihani.

(Surah al-Ahzab 33:5) 
Ayat ini merupakan dalil kepada larangan menasabkan anak angkat kepada bukan ayah kandung (alJassas, 1984; al-Qurtubi, 1964). Al-Zuhayli (1998) menyebut ayat ini adalah ayat ahkam yang mana terdapat beberapa larangan bagi penasaban anak kepada bukan bapa kandungnya. Penafsiran ayat ini juga dikaitkan dengan beberapa hadis yang juga memberi suatu garis panduan yang sangat jelas dalam permasalahan nasab dalam Islam (al-Jassas, 1984). Konteks penurunan ayat ini pada zaman Rasulullah s.a.w. adalah untuk menunjukkan peri pentingnya nasab yang mana pada ketika tersebut Rasulullah mempunyai anak angkat yang bernama Zayd yang tinggal dengan baginda sejak dari kecil. Setelah sekian lama tinggal dengan Rasulullah s.a.w. maka datang keluarga Zayd untuk mengambilnya pulang kembali kepada keluarga asal. Maka setelah persetujuan dicapai bahawa Zayd ingin terus tinggal bersama Rasulullah s.a.w. dan sejak dari peristiwa tersebut, maka masyhurlah Zayd sebagai anak baginda sehinggakan masyarakat Mekah ketika tersebut memanggil Zayd dengan gelaran Zayd bin Muhammad, bukan Zayd bin Harithah. Ayat ini kemudiannya mengubah situasi tersebut dan para sahabat tidak memanggil dengan gelaran tersebut lagi (al-Qurtubi, 1964). Hadis yang direkodkan oleh Muslim (1981) menyebut:

$$
\text { ....من ادُّعى إلى غيرِ أبيه ، وهو يعلُُ أنه غيرُ أبيه ، فالجنةُ عليه حراجٌ ... }
$$

Ertinya:...Barangsiapa yang mengaku orang lain sebagai ayahnya, dan dia mengetahui bahawa orang tersebut bukan ayahnya, maka diharamkan syurga ke atasnya...

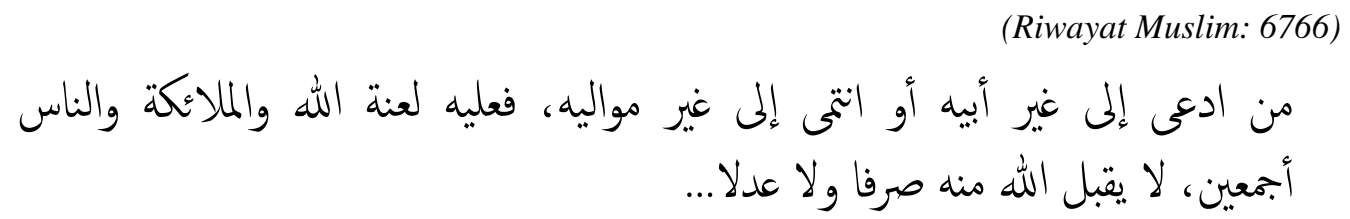

Ertinya:...Barangsiapa yang mengaku orang lain sebagai ayahnya atau menasabkan dirinya kepada selain dari tuannya, maka ke laknat Allah, para malaikat dan manusia seluruh ke atasnya, tidak diterima Allah daripadanya tukaran dan tebusan...

(Riwayat Muslim: 63)

\subsection{Pemberian Nafkah, Berbuat Baik Kepada Kedua Ibu Bapa dan Hukuman Qisas}

Wajhu dalalah bagi ayat ini menunjukkan bahawa kewajipan untuk memberi nafkah adalah kepada ayah (Zaydan, 1976). Hal ini merujuk kepada dalälah ishārah dari ayat 233 Surah al-Baqarah:

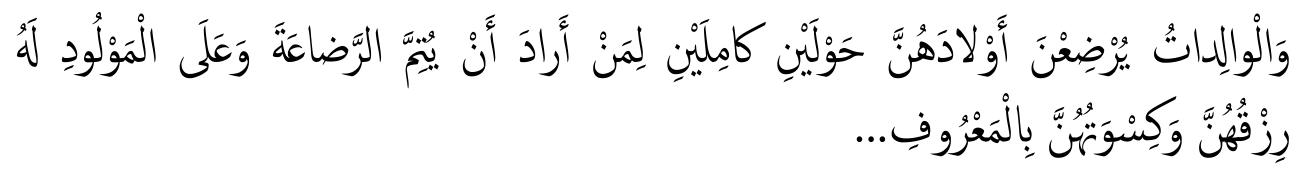

Ertinya:Dan ibu-ibu hendaklah menyusukan anak-anak mereka selama dua tahun genap iaitu bagi orang yang hendak menyempurnakan penyusuan itu; dan kewajipan bapa pula ialah memberi makan dan pakaian kepada ibu itu menurut cara yang sepatutnya...

(Surah al-Baqarah 2:233)

Kalimah ' $ل$ ' pada ayat tersebut mengandungi lām al-Ikhtiṣāṣ (pengkhususan) secara jelas mengisyaratkan kepada si bapa kerana kata ganti nama dalam kalimah tersebut merujuk kepada seorang lelaki (Amir Badshah, t.t.). Apa yang difahami dari sudut dalalah isharah adalah penasaban seseorang anak itu adalah kepada ayahnya sebagaimana kewajipan untuk memberi nafkah hanya wajib kepada si bapa bukan kepada ibu (al-Hafnawi, 2002; al-Taftazani, t.t.). Hal ini juga diulas oleh kebanyakan ulama' usul al-Figh yang terkemuka dalam kitab-kitab tersebut samada dari jalan al-Mutakalimin dan juga jalan al-Ahnaf (Abu Zahrah, 1958; Zaydan, 1976). Maka adalah menjadi kewajipan kepada si bapa bukan si ibu untuk menyediakan nafkah kepada anak dari sudut perbelanjaan makan dan pakaian mereka dengan kadar 
' $U r f$ '. Maka cara penasaban itu penting kerana sekiranya tidak dinasabkan secara betul, maka dibimbangi akan berlakunya pengabaian terhadap hak-hak nafkah dan tanggungjawab seorang ayah terhadap anaknya seperti yang disebut oleh Rasulullah s.a.w. dalam hadis 893, 2558 151, 7138, 5188 dan 2751 seperti direkodkan oleh al-Bukhari (2001).

Surah al-Isrā' ayat 23 dan Surah Luqman 14 merekodkan bahawa suruhan berbuat baik kepada kedua ibu bapa adalah suatu kewajipan. Ayat ini menegaskan bahawa kewajipan untuk berbuat baik kepada ibu dan bapa adalah merangkumi generasi sebelum ibu bapa tersebut iaitu termasuklah datuk dan nenek dan ke atas (Zaydan, 1976). Begitu juga dengan suruhan untuk berbuat baik kepada keluarga sendiri dalam beberapa ayat al-Qur'an seperti ayat 38 Surah al-Rüm dan juga hadis nombor 1977 dalam Sunan Ibnu Mājah (t.t.) dan 3895 dalam Sunan al-Tirmizi (1998). Suruhan dalam dalil-dalil tersebut tidak akan sampai maksudnya jika institusi kekeluargaan tidak wujud hasil dari kecelaruan nasab dan ketiadaan identiti keturunan. Hal ini termasuklah juga perihal dosa kepada kedua ibu bapa. Kehilangan susur galur keturunan menyebabkan tuntutan agama ini akan terhalang daripada dilakukan kerana institusi kekeluargaan itu sendiri sudah tiada identiti. Bahkan, kepentingan nasab dalam Islam tidak terhad terhadap itu sahaja. Islam telah memberi suatu garis panduan tentang adab kehidupan Islam berkaitan nasab di dalam undang-undang Qisas yang menyatakan bahawa antara syarat diwajibkan Qisas adalah seseorang yang pembunuh tersebut bukanlah dari kalangan bapa, datuk sebelah bapa dan seterusnya ke atas kerana ayah adalah sebab wujudnya si anak (al-Harayri, 1999; Ibn 'Ashur, 2001). Hukum ini akan gagal dilaksanakan sekiranya identiti keturunan antara ayah dan anak tidak dapat dikenalpasti. Boleh jadi juga si ayah tersebut membunuh anak angkatnya dan mengelak daripada dikenakan Qisas. Maka di sini akan berlakunya kontradiksi terhadap apa yang dinyatakan oleh Ibn 'Ashur (2001) mengenai maqasid tahsri' jinā'ie yang antaranya menekankan kepada keadilan kepada sesama manusia.

\subsection{Pewarisan Harta dan Pengharaman Nikah}

Sementara itu, dalam bab pewarisan harta, nasab juga memainkan peranan penting dalam nisab pembahagian harta tersebut. Sekiranya anak yang meninggal dunia si ayah juga akan termasuk dalam bahagian mereka yang mewarisi harta terbabit dan begitulah sebaliknya. Akan tetapi, sekiranya si anak tidak dinasabkan atau dibinkan kepada si ayah oleh sebab si ayah bukan ayah kandungnya atau si anak tersebut sendiri adalah hasil daripada perzinaan, maka si anak tidak akan mewarisi harta 'ayah biologi'nya begitu juga sebaliknya. Hal ini adalah banyak disebut dalam perbahasan hukum mirath (harta peninggalan si mati). Walau bagaimanapun, si 'ayah biologi' ${ }^{2}$ boleh mewarisi dan mewariskan harta kepada anak hasil zina beliau dengan cara wasiat begitu juga sebaliknya. Hal ini juga berkait rapat dengan kaedah pewalian dan pengharaman nikah dalam Islam. Dalam rukun nikah, wali ${ }^{3}$ adalah bertanggungjawab untuk hadir dan memberi keizinan kepada perempuan di bawah jagaannya untuk bernikah. Oleh yang demikian, penjagaan nasab penting bagi memudahkan urusan pernikahan yang juga mempunyai maqasid untuk menjaga keturunan. Nasab juga adalah suatu rantaian penting yang wajib dijaga bagi mengelakkan berlakunya pernikahan fasid (rosak). Pengharaman nikah dengan beberapa kelompok yang mempunyai pertalian nasab seperti yang dijelaskan dalam ayat 22 hingga 24 dalam Surah

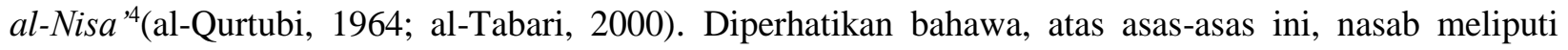

${ }^{1}$ Kadar 'urf yang dimaksudkan adalah tidak ditetapkan bilangan dan ukurannya tetapi mengikut kebiasaan setempat dan waktu tesebut.

2 Terma ini digunakan bagi merujuk kepada sumber benih lelaki yang menghasilkan zuriat tanpa ikatan perkahwinan yang sah.

${ }^{3}$ Wali yang dimaksudkan di sini adalah wali mujbir yang secara umumnya ditentukan melalui hubungan nasab iaitu samada ayah kepada perempuan tersebut atau saudara-saudara lelakinya dan lain-lain (Al-Mawsü'ah alFiqhiyyah al-Kuwaytiyyah, 1995).

${ }^{4}$ Ayat ke 22 menjelaskan tentang pengharaman nikah terhadap wanita-wanita tertertentu atas dasar nasab. Melihat dari sudut nasab, ayat tersebut merujuk kepada: 1. Ibu-ibu (nenek dan ke atas, samada kandung mahupun tiri) 2. Anak-anak perempuan (cucu-cucu perempuan dan ke bawah, samada anak kandung ataupun tiri). 3. Adik-beradik kandung perempuan. 4. Adik-beradik bapa yang perempuan. 5. Adik-beradik ibu yang perempuan. 5. Anak saudara perempuan dari adik-beradik lelaki 6. Anak saudara perempuan dari adik-beradik perempuan. 7. Ibu 
kepentingan kepada pelbagai cabang dalam Islam termasuk ibadat, muamalat, munakahat dan jinayat. Maka pensabitan penting bagi menjamin ketepatan nasab agar setiap cabang shari'ah yang disebutkan mencapai maqasidnya (al-Shātịīi, 1997).

\subsection{KAEDAH PENSABITAN NASAB DALAM ISLAM: SOROTAN RINGKAS TERHADAP AL-QIYAFAH}

Islam mempunyai kaedah tersendiri dalam mensabitkan nasab seseorang. Antara kaedah yang dibahaskan oleh para ulama' dahulu hingga sekarang adalah melalui al-Firash, al-Qiyafah dan al-Iqrar. Al-Firash dari segi bahasa merujuk kepada persetubuhan diambil sempena tempat berlakunya persetubuhan tersebut iaitu al-Firash (al-Zuhayli, t.t.). Al-Qiyafah pula bermaksud pemadanan fizikal sesuatu objek hidup dengan fizikal sesuatu objek yang lain. Ilmu ini pada zaman Rasulullah dipelopori oleh sebahagian dari kaum Arab antaranya Bani Mudlij yang mana terkenal dengan beberapa kisah pada zaman nabi antaranya adalah kisah Usamah dan anaknya Zayd. Maksud al-Iqrār pula adalah pengakuan dan ianya terbahagi kepada pengakuan dari pihak si bapa dan juga si anak. Dengan al-Iqrar, si bapa boleh mengaku yang dia mempunyai anak yang bernama si fulan dan sebaliknya. Hakim akan memutuskan sama ada dalam pengakuan tersebut terdapat keraguan atau tidak serta boleh meminta untuk mendatangkan bukti sokongan kepada pengakuan tersebut. Hakim juga boleh melihat kepada al-Qarinah atau petanda yang lain sekiranya berlaku perebutan kepada anak dengan jalan al-Iqrar yang dilakukan oleh lebih dari satu pihak ${ }^{5}$. Nasab anak juga disabitkan melalui kehamilan yang mencapai tempoh ${ }^{6}$ tertentu. Terdapat beberapa lagi kaedah yang diperselisihkan ulama' dan perlu perbahasan yang mendalam seperti al-Bayyinah, al-Simà' 'dan Hukm al-Qadhi.

Fokus literatur adalah kepada al-Qiyafah dan perkaitan dengan pensabitan nasab dalam Islam. Terma al-Qiyafah secara literal bemaksud 'menjejak' atau 'menelusuri' yang berasal dari bahasa klasik Arab (alTabari, 2000; Ibn Manzur, 1994). Ianya dipercayai digunakan dalam dua keadaan; sama ada terhadap haiwan atau manusia di atas tanah yang dikenali sebagai (qiyafat al-Athar), dan penelitian terhadap trait fizikal yang terdapat pada badan manusia untuk melihat kemiripan (syabah) yang kemudian dapat menentukan pertalian nasab dan perkaitan kekeluargaan seseorang anak dengan ibu bapanya yang dikenali sebagai (qiyafat al-Bashar) (al-Zuhayli, 1998). Al-Qaif pula adalah seorang yang berkemahiran, berkeupayaan, kepakaran, dan berpengetahuan serta cukup dipercayai oleh masyarakat untuk mempraktikkan al-Qiyafah. Direkodkan dalam catatan klasik bahwa mereka yang dikenali sebagai al-Qaif bukanlah spesifik kepada puak atau kaum tertentu bahkan al-Qaif adalah sesiapa sahaja yang mempunyai cukup syarat untuk mengamalkannya. Shabana (2012) menyebut bahawa peranan dan profesion yang dimainkan oleh al-Qaif adalah seolah-olah peranan pakar forensik dan saintis pada masa kini. Daripada rekod, sahabat bernama Mujazziz al-Mudlaji daripada Bani Mudlij, Umar al-Khattab dan ayahnya alKhattab bin Nufayl, Abu Ubaydah al-Jarrah dan juga bani Asad adalah antara mereka yang mahir dalam bidang ini (Hoyland, 2005; Shabana, 2012).

susuan. 8. Adik beradik perempuan sepersusuan. 9. Ibu-ibu mertua 10. Anak tiri dari perempuan yang telah dicampuri 11. Menantu dari anak kandung 12. Menghimpunkan dua adik-beradik perempuan yang bersaudara.

${ }^{5}$ Kes seperti ini pernah berlaku pada zaman Nabi Sulaiman terhadap dua orang wanita yang mengaku memiliki bayi yang sama selepas serigala membaham salah seorng anak mereka. Nabi Dawud memutuskan bahawa anak tersebut adalah milik wanita yang lebih tua, akan tetapi selepas membawa perkara tersebut kepada Nabi Sulaiman, Nabi Sulaiman mengacah untuk mengerat anak tersebut kepada dua bahagian, maka terzahirlah bahawa wanita yang sebenarnya mempunyai hak terhadap anak tersebut lebih rela anak tersebut diserah kepada wanita yang lain. Ini adalah petanda atau disebut al-Qarinah yang menyaksikan bahawa seorang ibu sebenar mempunyai kasih sayang yang luar biasa terhadap anak kandungnya. Peristiwa ini direkodkan dalam hadis bernombor 1720 oleh Imam Muslim (1981).

${ }^{6}$ Tempoh yang disebutkan mempunyai batasan terendah dan tertinggi. Ittifaq ulama' mengatakan bahawa tempoh terendah untuk sesuatu kehamilan bagi dinasabkan adalah enam bulan manakala paling tinggi adalah empat tahun bagi pendapat ulama-ulama'mazhab shafi'i, sebahagian hanabilah, dan satu pendapat dari malikiyyah, manakala dua tahun bagi pendapat hanafiyyah dan Imam Ahmad, dan lima tahun pula bagi pendapat yang masyhur dari Imam Malik (Al-Mawsü'ah al-Fiqhiyyah al-Kuwaytiyyah, 1995). 
Tidak ada dalil yang mengisyaratkan secara langsung yang menyatakan al-Qiyafah adalah metod untuk mengesahkan nasab sama ada dari al-Quran mahupun Sunnah. Namun yang ada adalah isyarat secara tersirat yang secara tidak langsung meletakkan al-Qiyafah sebagai suatu metod pengesahan nasab. Contohnya dalam hadis berkaitan dengan hukum li'an, disebut juga mengenai kemiripan (syabah) yang dapat dikenalpasti dari ciri-ciri fizikal oleh al-Qaif (Ibn Rajab, 1996). Hal ini mendorong kepada pengkelasan al-Qiyafah sebagai metod sampingan untuk menentukan nasab. Dalil yang paling kuat menyokong al-Qiyafah sebagai cara penentuan nasab adalah dari hadis dari Sahih Muslim (1981) yang diriwayatkan oleh A'ishah r.a.:

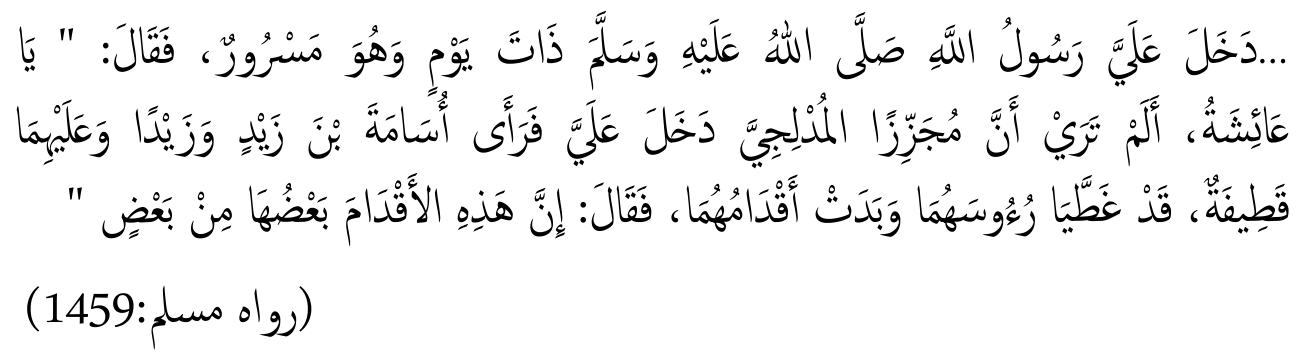

Ertinya: Bahawa Rasulullah s.a.w. suatu hari datang menemuiku dengan gembira dan wajah berseri-seri lalu beliau bersabda: Apakah kamu tidak melihat tadi Mujazziz al-Mudliji memandang Usamah bin Zayd dan Zayd bin Harithah dan kedua mereka berada di bawah selimut, telah tertutup kepala mereka berdua dan terserlah kaki mereka berdua lalu dia berkata: Sesungguhnya sebahagian dari kaki-kaki ini berasal dari sebahagian yang lain (mirip).

(Riwayat Muslim: 1459)

Keadaan Rasulullah s.a.w. yang gembira dengan kedatangan dan pendapat yang diutarakan oleh Mujazziz telah mendorong kepada penerimaan al-Qiyafah oleh ulama' fiqah sebagai salah satu metod penasaban atau pengesahan nasab. Majoriti ulama' melainkan dari mazhab Hanafi menerima al-Qiyafah sebagai metod penasaban selagi mana ia tidak bertentangan dengan hadis al-walad li al-firasy dan juga prosedur li'an. Hal ini adalah kerana tidak dapat dijumpai dalil melarang dari menggunakan al-Qiyafah dan juga kegembiraan Rasulullah s.a.w. dari peristiwa Mujazziz dalam kebanyakan hadis sahih. Ulama' mazhab Hanafi tidak mengiktiraf al-Qiyafah sebagai metod mengesahkan keturunan dengan alas an bahawa al-Qiyafah adalah berasaskan suatu perkara yang tidak pasti dan dhan. Penentuan nasab seharusnya menggunakan metod yang telah ditetapkan oleh shari'ah Islam seperti firash bahkan dari hadis tersebut mereka berpendapat bahawa keturunan dan nasab Usamah serta Zayd telah ditetapkan melalui al-firasy dan bukan al-Qiyafah. Dalam menjawab kritikan tersebut, majoriti ulama' mendatangkan hujah dari hadis-hadis kuat yang lain menyokong penggunaan al-Qiyafah dalam hal menentukan nasab. Al-Qarrāfi (t.t.) dalam kitabnya al-Furuq menyifatkan bahawa hadis-hadis seperti berkaitan 'percampuran mani lelaki dan perempuan mewujudkan syabah', serta 'hadis-hadis berkaitan li'an yang disertakan bersama ciri fizikal anak yang akan lahir' adalah menunjukkan keabsahan alQiyafah sebagai metod penentuan nasab. Jelas dari huraian ringkas ini, majoriti ulama' selain dari mazhab Hanafi menerima al-Qiyafah sebagai salah satu daripada metod penasaban anak.

\subsection{SAINS FORENSIK DAN KETAMADUNAN ISLAM}

Secara ilmiahnya, sains forensik tidak dinamakan sebagai sains forensik di dalam Islam, dan ianya perkataan tersebut bukanlah berasal dari bahasa Arab. Bahkan forensik adalah kata nama yang berasal dari perkataan 'forensic' yang bermaksud seni penghujahan (Kiely, 2000; M.Crim, Keith Inman, \& Rudin, 2001; Ahmad Syukran Baharuddin et al., 2015) dan juga boleh didefinisikan sebagai 'pengaplikasian pengetahuan dan ilmu saintifik bagi menyelesaikan masalah perundangan; khususnya analisis saintifik bagi bukti fizikal' (Webster's, 1996). Manakala adjektif bagi 'forensic' pula melambangkan suatu perkaitan, penggunaan, perbincangan umum dan penghujahan yang lebih spesifiknya di mahkamah atau juga melambangkan kepunyaan, pengguanaan, kesesuaian di mahkamah dan penghujahan awam. Pada zaman empayar Roman, Senat yang bersidang pada masa tersebut telah 
menamakan tempat persidangan mereka sebagai 'forum'. Perkataan 'forensic' sebenarnya bermaksud 'of the forum' yang bermaksud hak penghujahan di mahkamah (Siegel, 2007). Alfonso R. Gennaro, Audrey Hart Nora, James J. Nora, Richard W. Stander, and Weiss (1935, p. 525) dalam Kamus Perubatan Blakenstion's Gould, mengatakan bahawa perkataan 'forensic' adalah berasal dari bahasa Latin, forensis yang juga bermaksud 'of the forum', kepunyaan mahkamah atau undang-undang. Begitu juga perkataan 'sains' yang diambil dari perkataan 'scientia' yang bermaksud ilmu (Alfonso R. Gennaro et al., 1935, p. 1226). Ia juga berasal dari perkataan 'scire', yang bererti 'untuk mengetahui'- yang mana ianya adalah sebahagian daripada sistem ilmu yang berasaskan daripada pemerhatian dan eksperimen. Glugston (1998) pula menyebut bahawa sains forensik adalah pengaplikasian teknik saintifik dalam penyiasatan sesuatu kes. Kesimpulannya penakrifan sains forensik adalah merujuk kepada suatu cabang ilmu sains yang diperlukan dalam proses penyiasatan membantu dalam pembuktian mahkamah (Pass, 2009).

Secara kesimpulannya, untuk mengaitkan sesuatu sains dengan elemen forensik adalah tidak begitu mudah. Sains asas hendaklah dikaitkan dengan elemen forensik iaitu adanya penyiasatan bagi sesuatu kes atau proses merungkai keraguan sesuatu insiden (Umi Kalthom Ahmad \& Yacob, 2003). Sharma (1989) menyebut bahawa sesuatu elemen forensik perlu mempuyai tiga asas perkaitan antara; penjenayah, tempat kejadian dan bukti jika kes tersebut melibatkan jenayah. Analisis sains sama ada dari sudut biologi, kimia atau fizik hendaklah selari dengan tiga elemen forensik yang disebutkan. Sekiranya tidak, ianya hanyalah analisis sains yang normal dan dikenali dengan basic science. Sains forensik juga didasari dengan pelbagai prinsip asas seperti Prinsip Pertukaran Locard, Prinsip dalam Pembezaan, Prinsip Individualiti dan Analisis serta Prinsip Pembuktian dan dengan itu, sesuatu analisis atau penyiasatan forensik tidak dapat tidak akan menggunakan prinsip-prinsip ini yang dipercayai telah digunakan sejak awal penemuan sains forensik lagi (Baharuddin, Ruskam, \& Yacob, 2015; Kamdar \& Pandey, 2011; Kirk, 1963; Sharma, 1989).

Walau bagaimanapun, terminologi, kaedah dan prinsip asas forensik tersebut tidak banyak diulas dalam sejarah Islam menggunakan 'terma sains forensik'. Melihat dari aspek terminologi, sains forensik diertikan sebagai al-Tibb al-Shar'i atau al-Tibb al-Qad̄a $\bar{i}$ yang lebih dekat diertikan kepada forensik patologi. Definisi ini diberikan oleh Yusuf K. Hitti (t.t., p. 258) dalam terjemahan beliau. Fuqahä' yang kebanyakannya dari zaman dahulu yang dipanggil ulama 'a al-Qadim (ulama terdahulu) tidak banyak membicarakan tentang definisi tepat sains forensik dalam penulisan-penulisan mereka melainkan kepada beberapa definisi umum dan ringkas yang didapati dari pengkaji-pengkaji dalam bidang ini contohnya 'Azzām (2008, p. 28). Hal ini adalah disebabkan terma 'sains forensik' tidak masyhur dan perkembangan teknologinya masih di tahap rendah. Dari kaca mata kesempurnaan Islam, dengan mudah dapat dilihat bahawa sains forensik sebenarnya telah ditemukan dan digunakan sejak dari asas penurunan al-Quran dan Sunnah lagi. Beberapa kes berkaitan penggunaan elemen forensik telah dijelaskan dalam al-Quran dan hadis sama ada secara jelas atau samar-samar. Kes-kes yang antara contohnya diceritakan secara jelas dalam Surah Yūsuf ayat 18 (al-Suyuti, 1993; Sayyid Qutb, 1993; Sha'rawi, 1997), ayat 27 (Sayyid Qutb, 1993, p. 1977), dan juga pada ayat 94. Ayat-ayat tersebut kesemuanya adalah antaranya berkaitan dengan pengesanan bau, kesan koyakan pada baju dan saksi (konstruk bagi siasatan tempat kejadian) dan penggunaan darah palsu (fakelfabricated blood) dari kambing yang digunakan oleh saudara Nabi Yusuf dalam kes tragik penipuan saudara maranya tentang kematian Nabi Yusuf kepada ayah mereka Nabi Ya'qub (Ibn al-Qayyim, t.t.; Ibn Farhun, 1986; Ahmad Syukran Baharuddin et al., 2015).

Sains forensik juga pernah dalam banyak situasi diketengahkan penggunaannya dalam beberapa kes. Kes pembunuhan Abu Jahal dalam peperangan Badr oleh dua orang pemuda bernama Mu'àz (al-Bukhari, 2001) dan kes penyiasatan Li'an bagi Hilal Bin Umayyah (Ibn majah, 2007) juga antara kes yang menggunakan sains forensik dalam penghakiman. Kes-kes ini secara contohnya menggunakan elemen forensik yang pada zaman kini boleh diandaikan seperti Blood Spatter Analysis (BPA) dan juga sisasatan tempat kejadian (Crime Scene Investigation). Penggunaan sains forensk juga digunakan untuk pengecaman mayat pada zaman lalu sekiranya terdapat mayat yang tidak dikenali seperti yang diceritakan oleh ramai ulama' silam seperti Ibn Farhun (1986) dalam Tabsirat al-Hukkam fi usul al-Aqdiyah wa 
Manahij al-Ahkam dan Ibn al-Qayyim (t.t.) dalam Turuq al-Hukmiyyah. Antara teks klasik yang secara jelas mempunyai elemen forensik patologi adalah seperti:

jika sekiranya seseorang menjumpai mayat di kawasan penempatan Muslim, dan padanya ada tali pinggang (zunnar) dan dia tidak berkhatan, jangan kebumikan dia di perkuburan Muslim, dan selesaikan kes ini selanjutnya menggunakan kaedah penempatan...'

Dan teks:

‘...dan jika sekira terdapat pada badannya kostum/pakaian (keagamaan yang melambangkan) kaum kafir seperti salib dan tali pinggang (zunnar) yang mana pada masa tersebut mayat Muslim bercampur dengan mereka (kafir); maka pakaian/kostum dan tanda digunakan untk membezakan (antara mereka)...'

(Ibn al-Qayyim, t.t.; Ibn Farhun, 1986)

Teks seperti ini biasanya terdapat dalam kitab-kitab klasik yang melibatkan perundangan dan huraian terhadap ayat 29 Surah al-Fath, ayat 273 Surah al-Baqarah (al-Qurtubi, 1964; al-Zayla'i, 1992; Ibn Farhun, 1986). Selain daripada itu, terdapat beberapa lagi kes pada zaman Nabi Muhammad (s.a.w) seperti kes seorang lelaki yang tidak mengakui anak tersebut dari darah keturunan beliau. Sebagai tambahan juga, kes seorang wanita yang mendakwa seorang lelaki baik dari kaum Ansar telah melakukan hubungan seksual dengannya juga turut menjadi penanda aras kepada penggunaan elemen forensik dalam ketamadunan Islam. Analisis forensik dibuat terhadap kesan mani dalam kes tersebut yang berlaku pada zaman Sayyidina 'Umar al-Khattab semasa beliau menjadi Khalifah (al-Najdi, 1970; Bahnasi, 1989; Ibn al-Qayyim, t.t.). Penggunaan air panas pada tompokan tersebut boleh dikira sebagai reagen dan Ibn Qayyim sendiri menyatakan bahawa ianya suatu yang menakjubkan (al-Zayla‘i, 1992; Ibn al-Qayyim, t.t.; Ramlee, 1997).

\subsection{Forensik Biologi Dan Penentuan Nasab Dalam Islam}

Biologi memainkan peranan yang penting dalam sains forensik. Ia adalah salah satu cabang yang besar dalam bidang ini sehinggakan dinamakan sebagai forensik biologi. Forensik biologi adalah suatu proses mengaplikasikan analisis biologi dan metod serologi dalam membantu dalam penyiasatan (Pass, 2009). Terdapat pelbagai cabang dalam forensik biologi seperti patologi, antropologi, entomologi, odontologi, serologi, dan analisis cap jari. Adalah telah dipercayai bahawa forensik biologi (cap jari) telah digunakan seawal 700 sebelum masihi oleh masyarakat China untuk menentukan identiti sesebuah dokumen dan hasil arca (Baharuddin et al., 2013; Sharma, 1989). Sebagai skop kepada kajian ini, dua cabang forensik biologi: Analisis trait fizikal dan serologi darah dihimpunkan sebagai suatu tema dalam kajian kes yang melibatkan nasab dalam Islam. Secara turutan sejarah, penemuan-penemuan besar ini bermula dengan trait fizikal oleh Gregor Mendel pada 1865 diikuti dengan penemuan antigen A, B, AB dan O pada tahun 1930-an dan penemuan DNA pada tahun1953 oleh James Watson dan Francis Crick.

\subsubsection{Trait Fizikal}

Trait fizikal ${ }^{7}$ bagi setiap organisma adalah salah satu asas yang penting dalam biologi (Henderson \& Lawrence, 2008). Menurut hukum Mendel, setiap pewarisan mewariskan genetik tersendiri yang mampu membentuk trait fizikal tertentu yang berbeza dengan yang lain. Apabila ia dihubungkan dengan pembuktian terhadap sesuatu kes, ia mencapai kepada maksud asas sains forensik yang mengaplikasikan sains sebagai salah satu cara dan kaedah untuk sampai kepada kesimpulan bagi sesuatu kes. Trait secara linguis bermaksud suatu kriteria atau ciri khas bagi sesuatu benda hidup manakala dalam istilah biologi ianya dikenali sebagai 'phenotypic traits' iaitu trait fenotip yang membawa maksud ciri-ciri dan karekter khusus terhadap fizikal yang terhasil daripada pewarisan genetik seperti warna mata, warna dan jenis rambut, jenis kerintingan rambut, arah rambut di bahagian hadapan, bentuk jari kaki dan bentuk telinga (Beckman, Böök, \& Lander, 1960; Henderson \& Lawrence, 2008). Trait fizikal ini juga menjadi asas

${ }^{7}$ Trait fizikal adalah ciri-ciri fizikal yang memberikan suatu pengecaman kepada individualiti seseorang pemilik trait tersebut. Trait yang dominan akan lebih menonjol dari trait yang resesif (Bateson \& Mendel, 1909). 
kepada salah satu daripada prinsip asas dalam sains forensik iaitu Prinsip Individualiti (Principle of Individualization $)^{8}$ dan Prinsip Perbandingan (Principle of Comparison) ${ }^{9}$ (Kamdar \& Pandey, 2011; Sharma, 1989). McDonald (2011) dalam kajiannya menyenaraikan lebih dari 15 trait fizikal yang boleh diwarisi dari ibu bapa termasuklah trait fizikal bagi cuping telinga, bentuk jari kaki, bentuk ibu jari termasuklah kadar kelembapan ear wax (kotoran dalam telinga) yang dipengaruhi oleh alel genetik yang juga mempengaruhi bau badan. Dengan mengambil contoh yang berkaitan dengan trait fizikal pada kaki, penjelasan ini mula dipelopori oleh Kaplan (1964) yang menyimpulkan bahawa kepanjangan ibu jari dan jari kedua kaki adalah diwarisi. Berikut adalah jadual bagi pewarisan trait fizikal pada kaki yang diadaptasi dari Kaplan (1964), Bateson dan Mendel (1909), dan Weldon (1902):

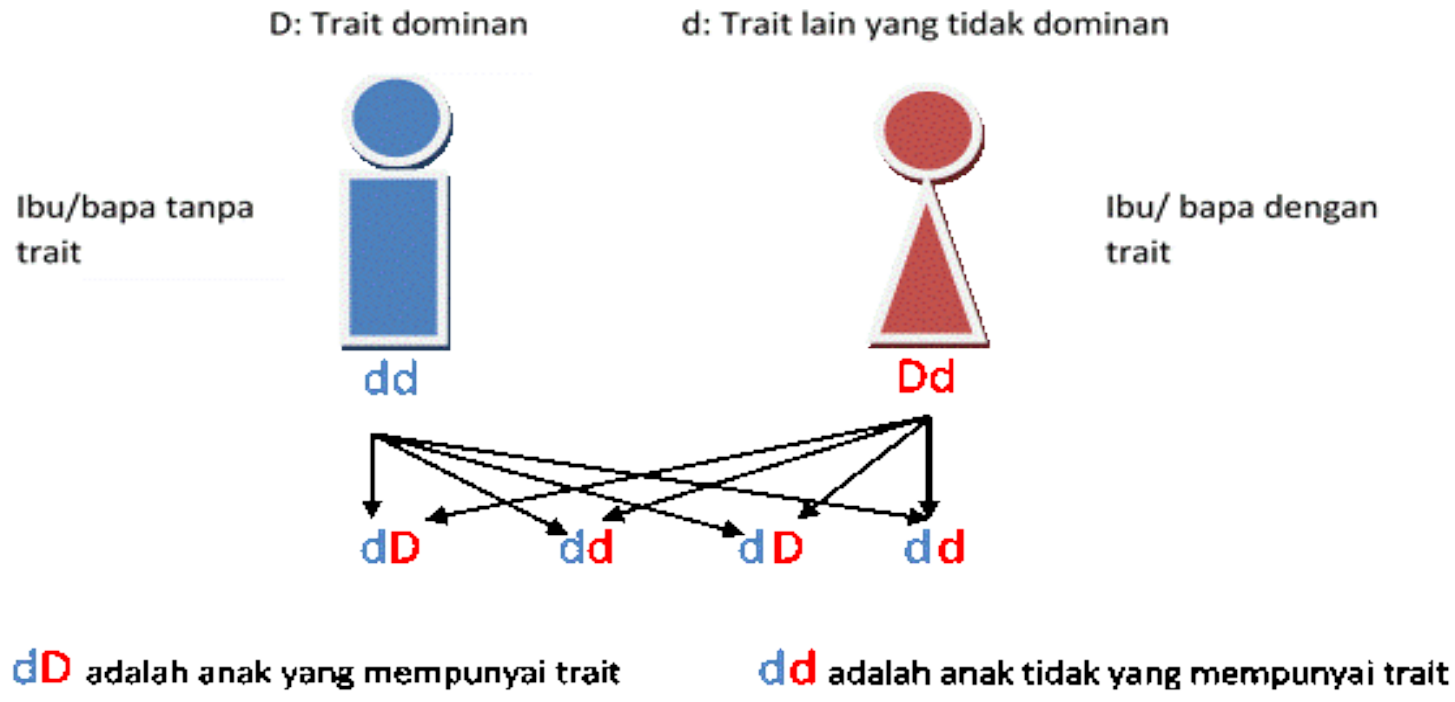

\section{Rajah 1: Hukum Pewarisan Mendel I}

Dengan ' $D$ ' adalah trait yang dominan dan 'd' adalah trait lain yang resesif jika dilihat dari carta ibu bapa yang mempunyai trait yang dominan akan mewariskan trait tersebut kepada anak dengan kebarangkalian 50\%. Sekiranya anak tersebut tidak mewarisi trait yang dominan tersebut, dia boleh juga mewarisi trait dominan yang lain yang diwariskan dari ibu dan bapanya. Trait-trait ini menjadi identity pengenalan kepada anak dan ibu bapa. Dalam analisis forensik bagi pembuktian nasab, trait fizikal yang terdapat pada ibu atau ayah dipadankan dengan trait yang terdapat pada anak dan juga sebaliknya dengan mengambil kira faktor resesif dan dominan ${ }^{10}$. Sekiranya terdapat trait-trait yang disebutkan seperti sebelum ini, maka kebarangkalian bahawa anak tersebut adalah dari zuriat ibu dan bapa tersebut adalah tinggi. Hal ini telah dibuktikan dengan pelbagai kajian mengenai hukum pewarisan genetik antaranya adalah dari kajian Roach et al. (2010), Monks et al. (2004) dan McKusick (1998). Menurut perspektif Islam, hukum pewarisan ini ada dasarnya apabila terdapat beberapa sumber yang kuat membincangkan perkara ini. Sumber tersebut antaranya adalah beberapa hadis yang agak terkenal dan masyhur direkodkan oleh Muslim (1981) daripada Aisyah ra.:

\footnotetext{
${ }^{8}$ Prinsip Individualiti mula dipelopori oleh pakar forensik, Leland Kirk pada tahun 1963. Beliau menyebut bahawa tujuan utama sains forensik adalah untuk memberi fokus kepada dua objek yang dianggap datang dari satu sumber yang sama tetapi punya ciri berbeza dan setiap objek di dalam alam adalah unik (Kirk, 1963).

${ }_{9}$ Prinsip ini menyatakan bahawa sebarang perbandingan terhadap sesuatu objek yang dianalisis hendaklah dibuat dengan membandingkan ia dengan suatu objek yang lain yang mempunyai kriteria dan ciri yang sama (Sharma, 1989).

${ }^{10}$ Resesif adalah ciri yang tidak menonjol pada seseorang yang telah dikalahkan dengan ciri dominan. Ianya tetap akan diwariskan kepada generasi berikutnya (Cummings, 2010).
} 


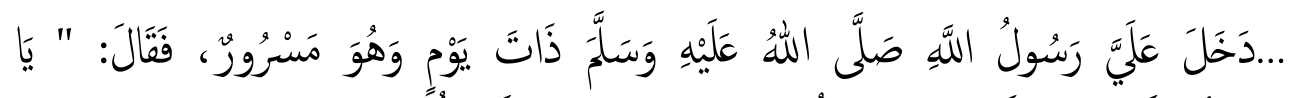

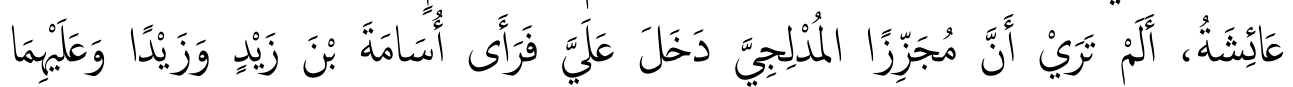

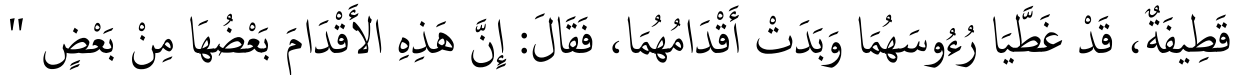

$$
\begin{aligned}
& \text { (1459: (رواه مسلم) }
\end{aligned}
$$

Ertinya: Bahawa Rasulullah s.a.w. suatu hari datang menemuiku dengan gembira dan wajah berseri-seri lalu beliau bersabda: Apakah kamu tidak melihat tadi Mujazziz al-Mudliji memandang Usamah bin Zayd dan Zayd bin Harithah dan kedua mereka berada di bawah selimut, telah tertutup kepala mereka berdua dan terserlah kaki mereka berdua lalu dia berkata: Sesungguhnya sebahagian dari kaki-kaki ini berasal dari sebahagian yang lain (mirip).

(Riwayat Muslim: 1459)

Begitu juga hadis-hadis dalam kitab li'an dalam Sahih Muslim seperti:

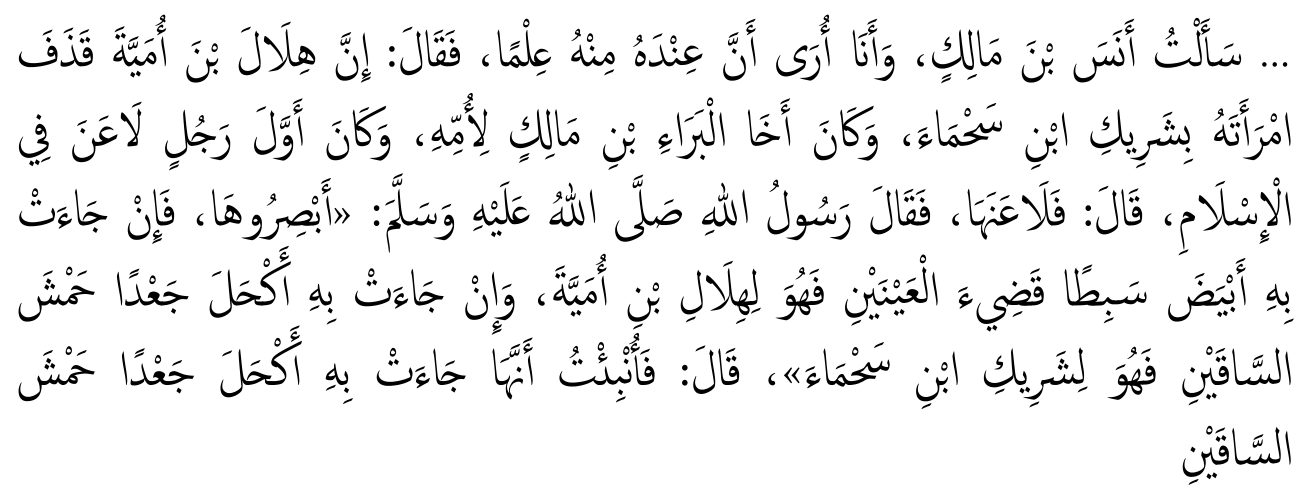

$$
\text { (متفق عليه) }
$$

Ertinya:...Aku bertanya kepada Anas bin Malik, dan aku mengetahui bahawa dia orang yang berilmu, maka dia berkata: Sesungguhnya Hilal bin Umayyah telah melakukan qadhaf kepada isterinya dengan Sharīk bin Sahmmā' iaitu saudara seibu kepada al-Barrā' bin Mālik, dan dia adalah orang terawal melakukan li'an dalam Islam, maka Anas berkata: Hilal kemudian melakukan sumpah li'an terhadap isterinya maka Rasulullah s.a.w. bersabda: Perhatikan perempuan tersebut nanti, jika nanti anaknya yang datang daripadanya putih berambut lurus dan mata agak merah, maka anak tersebut adalah daripada Hilal bin Umayyah, namun jika matanya agak hitam rambutnya kerinting, dan betisnya ramping, maka bayi tersebut adalah milik Sharìk bin Sahmā'. Anas berkata: Kemudian saya diberitahu bahawa anak tersebut bermata hitam berambut kerinting dan berbetis ramping...

(Muttafaqun 'alayh)

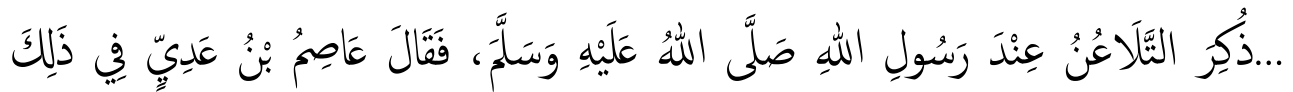

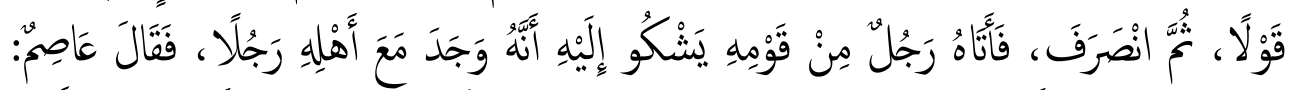

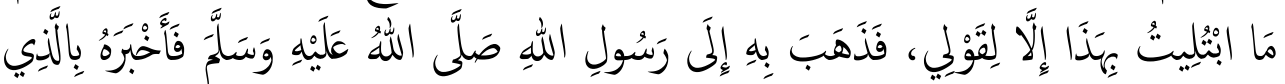

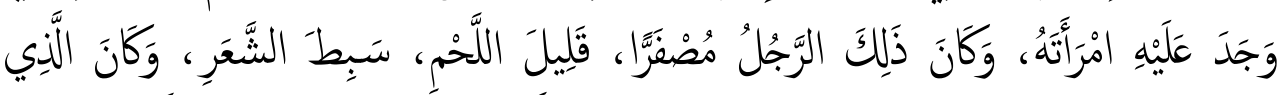

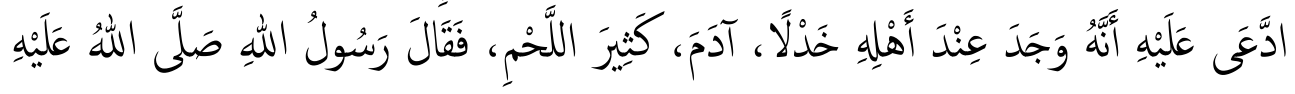


Ahmad Syukran Baharuddin et. al. / UMRAN - International Journal of Islamic and Civilizational Studies. vol. 2, no. 2 (2015) 11-29

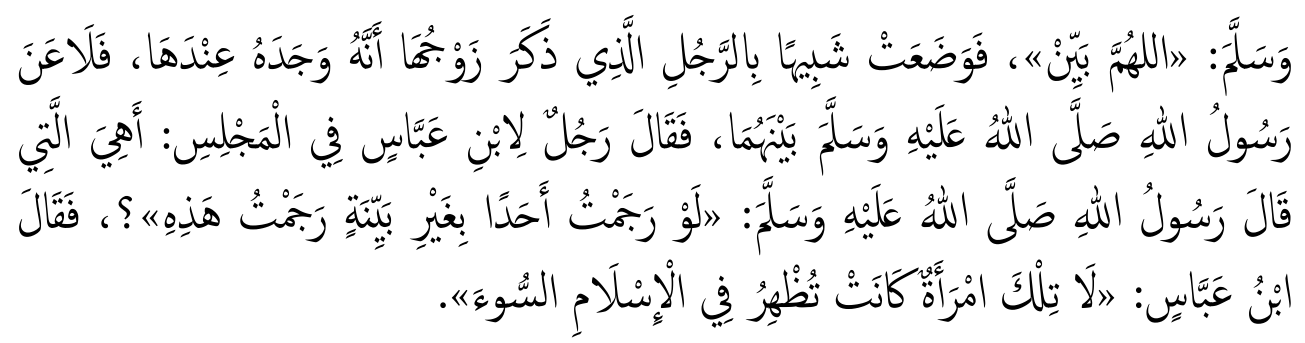

(1497: رواه مسالم)

Ertinya:...Satu peristiwa lian dilaporkan kepada Rasulullah s.a.w.., lalu `Asim bin Adi mengulasnya dengan suatu perkataan dan segera pergi. Kemudian datang seorang lelaki dari kaumnya mengadu bahawa dia mendapati seorang lelaki lain bersama isterinya. 'Asim berkata: Tidaklah aku diuji dengan pertanyaan ini kecuali karena perkataanku tadi. Dia pergi menemui Rasulullah s.a.w. bersama lelaki itu. Kepada beliau `Asim menyatakan lelaki yang mendapati isterinya bersama lelaki lain itu berkulit kuning, berbadan kurus dan berambut lurus. Sedangkan lelaki yang dituduh telah bersama isterinya mempunyai otot padat, bertubuh sasa, dan besar. Rasulullah s.a.w. berkata: Ya Allah, buktikanlah! Dan ternyata wanita itu melahirkan anak yang mirip dengan lelaki yang dituduh oleh si suami telah ditemui berada bersama isterinya. Maka Rasulullah s.a.w. memerintahkan sumpah lian dilakukan antara keduanya. Seseorang telah bertanya kepada Ibnu Abbas dalam sebuah majlis: Apakah ia wanita yang dikatakan Rasulullah s.a.w.. dalam sabdanya: Seandainya aku boleh merejam seseorang tanpa bukti, niscaya aku akan merejam wanita ini. Ibnu Abbas menjawab: Bukan, wanita tersebut adalah wanita yang secara terang-terangan melakukan kejahatan terhadap Islam.

(Riwayat Muslim: 1497)

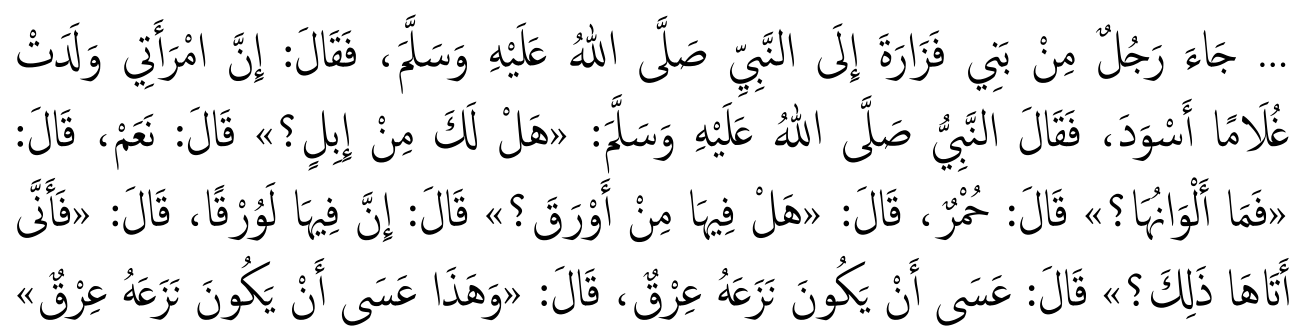

$$
\text { (رواه مسلم:1450) }
$$

Ertinya:...Seorang lelaki dari Bani Fazarah datang menemui Nabi s.a.w. dan berkata: Sesungguhnya isteriku telah melahirkan seorang anak berkulit hitam. Nabi s.a.w. bertanya: Apakah kamu mempunyai unta? Lelaki itu menjawab: Ya. Nabi s.a.w. bertanya lagi: Apa warnanya? Lelaki itu menjawab: Merah. Nabi s.a.w.. bertanya: Apakah ada warna kelabu? Lelaki tadi menjawab: Ya, ada warna kelabu. Nabi s.a.w. bertanya: Dari manakah datangnya warna kelabu itu? Lelaki itu menjawab: Mungkin sebab keturunan. Nabi s.a.w. bersabda: Begitu juga dengan anakmu, mungkin sebab keturunan.

(Riwayat Muslim: 1450)

Hadis-hadis tersebut secara ishārah memberi suatu pengakuan bahawa trait fizikal yang terdapat pada anak-anak yang lahir merupakan pewarisan daripada ibu dan bapa mereka. Hadis berkaitan Zayd bin Harithah misalnya membahas tentang pewarisan trait fizikal yang terdapat pada kaki. Dalam hadis yang pertama disebut secara jelas bagaimana seorang Qaif dapat menentukan paterniti seorang anak dengan ayahnya dengan melihat kepada kaki kedua-dua mereka. Pernyataan Mujazziz bahawa sebahagian kaki tersebut adalah berasal daripada sebahagian yang lain adalah merujuk kepada kemiripan antara dua kaki. Bahkan, kemiripan antara dua kaki tersebut ditentukan dalam keadaan tuan punya kaki tersebut berselimut kepala mereka. Hukum pewarisan menyatakan bahawa bentuk kaki adalah termasuk dalam ciri-ciri pewarisan genetik. Dengan hal yang demikian, melalui pengecaman trait fizikal antara anak dan 
ayah serta ibu, yang dibincangkan oleh ulama' melalui istilah syabah, penyelesaian mengenai hal ehwal penasaban menjadi lebih mudah.

Sementara itu, dalam dua hadis berikutnya yang diriwayatkan oleh Imam Muslim yang berkisar mengenai ahkam li'an mengandungi elemen paterniti melalui trait fizikal dengan suatu hipotesis sekiranya anak yang dilahirkan mirip kepada lelaki yang dimaksudkan, ianya adalah dari benih lelaki tersebut. Hilal bin Umayyah mempunyai trait fizikal rambut yang lurus dan mata yang berwarna agak merah. Hal ini adalah disebabkan oleh pewarisan genetik yang diwariskan dari keturunan Hilal. Sifat ini adalah salah satu dari trait fizikal yang resesif. Manakala rambut keriting pula adalah trait fizikal yang dominan. Pernyataan Rasulullah dalam hadis tersebut yang memberikan suatu hipotesis memberi suatu bayangan bahawa anak yang dilahirkan mempunyai ciri-ciri pewarisan trait yang khusus. Bahkan pencirian karekter yang disebut oleh Rasulullah adalah agak terperinci sehingga menyebut mengenai warna mata dan sifat rambut yang mana pada zaman kini ianya adalah termasuk dalam sifa-sifat resesif dan dominan dari pewarisan genetik. Hadis yang terakhir disebutkan juga menunjukkan secara langsung pernyataan dari Rasulullah bahawa pewarisan genetik dari gen terdahulu memungkinkan anak yang dilahirkan mempunyai ciri warna kulit yang berbeza dengan induk. Hal ini menunjukkan bahawa inferens yang disebut oleh Rasulullah membuka kepada suatu penelititian yang lebih mendalam mengenai pewarisan baka.

Keseluruhannya, perkaitan antara trait fizikal dengan penyelesaian hukum-hakam berkaitan keturunan adalah suatu bentuk penelitian forensik. Penggunaan elemen biologi dan asas genetik dalam menyelesaikan dan menyiasat pertikaian berkaitan nasab adalah suatu bentuk analisis forensik. Konsep syabah (kemiripan) yang dibincangkan oleh ulama' terdahulu lebih mudah dibahaskan melalui analisis DNA. Dengan analisis DNA, trait, gen, penyakit serta ciri-ciri boleh dianalisa dengan lebih tepat bagi menentukan keabsahan trait fizikal yang dianalisa secara luaran oleh pakar forensik.

\subsubsection{Serologi}

Dalam penyiasatan forensik, analisis serologi secara amnya adalah meliputi penyiasatan terhadap bendalir badan, sebagai contoh air liur, air mani, darah dan semua bendalir yang dijumpai di sesuatu tempat kejadian jenayah (Hill, 1997; Pass, 2009). Juga termasuk dalam serologi adalah pengkelasan kumpulan darah. Dari sudut sejarah, pengkelasan kumpulan darah mula ditemui oleh seorang doktor Austria yang bernama Karl Landsteiner yang berjaya menemukan tiga kumpulan asas bagi darah manusia yang pada ketika tersebut dilabel sebagai A, B, dan $C^{11}$ (Farhud \& Zarif Yeganeh, 2013; Landsteiner, 2013). Pada tahun 1901 tersebut beliau cuba mencari sebab kenapa terdapat beberapa pemindahan darah yang berjaya dilakukan tanpa sebarang komplikasi dan sebahagian yang lain membawa kepada kematian dalam abad tersebut (Learoyd, 2012; Welck, Borg, \& Ellis, 2010). Hasilnya, beliau menemui terdapat tiga kumpulan darah utama yang terbentuk selepas mencampurkan sel darah merah dengan serum darah dari pekerja beliau. Setahun kemudian kelas darah AB pula ditemui oleh rakan sekerja beliau Alfred Von Decastello dan Adriano Sturli (Premuda, 1978). Sebenarnya dalam sains, gen yang menentukan pengkelasan kumpulan darah manusia A, B, dan O terletak pada kromosom 9 (9q34.1) dan dikenali sebagai $\mathrm{ABO}$ glycosyltransferase yang mempunyai tiga bentuk alel ${ }^{12}$ dan mempunyai peranan dalam penghasilan glycoprotein. Penentuan kumpulan glycoprotein yang wujud di dalam darah seseorang adalah melalui pewarisan dari ibu bapanya dan seterusnya menentukan kumpulan darah yang dipunyai olehnya (Farhud \& Zarif Yeganeh, 2013). Ciri-ciri khusus unik bagi kumpulan darah pada seorang manusia adalah seperti jadual berikut:

${ }^{11}$ Kemudiannya ditukarkan kepada 'O' huruf pertama dalam bahasa German 'Ohne' yang bermaksud 'tanpa/tiada' atau 'kosong' (Farhud \& Zarif Yeganeh, 2013).

12 'Alel' adalah istilah yang berasal dari Yunani yang digunakan sebagai singkatan bagi 'alelomorf' yang bermaksud bentuk lain bagi gen atau kelainan yang mana dalam bidang biologi ianya berkaitan dengan kepelbagaian fenotip (Darden, 1991) 
Jadual 1: Kumpulan Darah dan Gen yang Terdapat dalam Darah

Kombinasi Genetik bagi Kumpulan Darah ABO

\begin{tabular}{cc}
\hline Kumpulan Darah & Gen yang terdapat dalam darah \\
\hline $\mathrm{A}$ & $\mathrm{AA}$ atau AO \\
$\mathrm{B}$ & $\mathrm{BB}$ atau BO \\
$\mathrm{AB}$ & $\mathrm{AB}$ \\
$\mathrm{O}$ & $\mathrm{OO}$ \\
\hline
\end{tabular}

Jadual 2: Kumpulan Darah Ibu Bapa dan Kumpulan Darah Anak

\begin{tabular}{ll}
\multicolumn{2}{c}{ Corak Pewarisan ABO } \\
\hline \multicolumn{1}{c}{ Kumpulan darah ibubapa } & \multicolumn{1}{c}{ Kumpulan darah anak } \\
\hline O dan $\mathrm{O}$ & $\mathrm{O}$ \\
$\mathrm{O}$ dan $\mathrm{A}$ & $\mathrm{O}$ atau A \\
$\mathrm{O}$ dan B & O atau B \\
O dan AB & A atau B \\
A dan A & A atau O \\
A dan B & O atau A atau B atau AB \\
A dan AB & A atau B atau AB \\
B dan B & O atau B \\
B dan AB & B atau A atau AB \\
AB dan AB & A atau B atau AB \\
\hline
\end{tabular}

Oleh kerana pewarisan ini adalah mengikut kepada Prinsip Pewarisan Mendel, maka kesimpulan yang boleh dibuat adalah kumpulan darah yang terdapat pada manusia akan kekal sepanjang hidupnya dan terbukti ianya adalah sebahagian daripada trait dan genetik yang diwarisi dari kedua ibubapa (Bateson \& Mendel, 1909; Weldon, 1902). Untuk itu, melalui ujikaji serologi bagi darah, beberapa kesimpulan umum boleh dibuat iaitu sekiranya diketahui kumpulan darah ibu dan ayah dapat diketahui kumpulan darah si anak, atau sekiranya terdapat darah si anak dan ibu untuk dianalisis maka kumpulan darah si ayah boleh diketahui. Sebagai contoh, jika kumpulan darah ibu adalah dari kumpulan ' $\mathrm{O}$ ' dan darah anak adalah dari kumpulan 'O', maka kumpulan darah bagi si ayah boleh terdiri daripada sama ada 'A', 'B' atau ' $O$ '. Maka sekiranya terdapat lelaki yang mendakwa anak tersebut dari nasabnya sedangkan dia adalah dari kumpulan darah ' $\mathrm{AB}$ ' maka tuduhan tersebut tidak berasas kerana kebarangkalian untuk kumpulan darah $\mathrm{AB}$ (dari lelaki tersebut) dan ' $\mathrm{O}$ ' dari anak tersebut hanya akan mewariskan anak yang mempunyai kumpulan darah 'A' dan 'B', bukan ' $O$ ' seperti dalam contoh yang diberikan. Satu lagi contoh adalah jika kedua ibu bapa mempunyai kumpulan darah ' $\mathrm{O}$ ' dan mendakwa seorang kanak-kanak yang mempunyai kumpulan darah ' $\mathrm{A}$ ', 'B' atau 'AB' sebagai anak mereka, maka dakwaan tersebut tertolak kerana anak mereka mengikut Prinsip Mendel sepatutnya hanya mewarisi kumpulan darah ' $O$ '.

Serologi darah ini menepati kewajaran bagi Prinsip Individualiti dalam sains forensik yang bertepatan dengan banyak kes yang disebut dalam sejarah Islam. Antara kisah yang pernah disebutkan dalam al-Qur'an adalah dari ayat 18 Surah yusuf mengenai perihal darah yang dilumur pada baju Nabi Yusuf yang dijadikan bahan bukti oleh adik-beradik baginda bahawa baginda dimakan serigala. Darah yang dilumur adalah darah kambing dan sebilangan riwayat menyatakan ianya adalah darah kijang (alQurtubi, 1964):

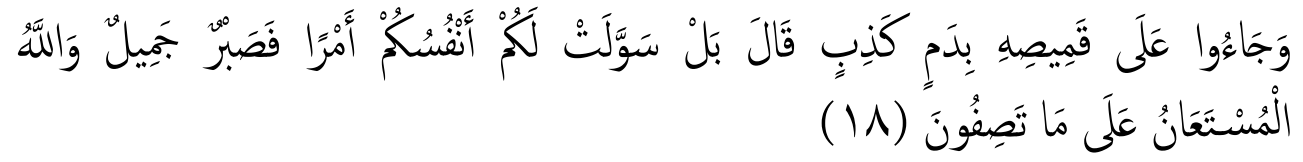


Ertinya: Dan (bagi mengesahkan dakwaan itu) mereka pula melumurkan baju Yusuf dengan darah palsu. Bapa mereka berkata: "Tidak! Bahkan nafsu kamu memperelokkan kepada kamu suatu perkara (yang tidak diterima akal). Kalau demikian, bersabarlah aku dengan sebaikbaiknya, dan Allah jualah yang dipohonkan pertolonganNya, mengenai apa yang kamu katakan itu."

(Surah Yusuf 12:18)

al-Qurtubi (1964) menyebut bahawa Sha'bi meriwayatkan bahawa darah tersebut boleh dimaksudkan dengan terdapatnya ciri-ciri perbezaan warna yang dapat dikenalpasti seperti berbezanya warna putih yang keluar dari kuku baru manusia dengan warna kuku lama. Hal ini bermaksud ada perbezaan terhadap darah tersebut dengan darah manusia lebih-lebih lagi ianya dari kambing yang mana Nabi Ya'kub mungkin mampu membezakannya memandangkan pengalaman lampaunya sebagai penternak kambing.

\subsection{PERBINCANGAN DAN SYOR KAJIAN}

Sesungguhnya nasab adalah suatu perkara yang sangat penting dalam Islam sehinggakan ianya diangkat menjadi salah satu daripada lima bahagian yang membentuk darūriyyāt al-Khamsah ${ }^{13}$. Rentetan itu, Islam menggariskan pelbagai kaedah dan ketetapan sama ada dari aspek menjaga kewujudan ${ }^{14}$ dan juga menghalang perkara yang boleh membawa kepada kehancuran ${ }^{15}$ kepada elemen nasab (al-Yubi, 2012). Ternyata dengan forensik biologi, nasab dapat ditentukan dan maqasid penjagaan nasab dapat dicapai. Akan tetapi, garis panduan yang menjadi tunggak asas dalam penjagaan nasab adalah terdiri daripada hukum-hakam yang telah diturunkan seperti pengharaman zina dan qadhaf serta hukuman had ke atas pelaku zina dan pelaku qadhaf sekiranya gagal mengemukakan bukti, penafian nasab dan pensyariatan li'an. Dalam hal berkaitan nasab, dua perkara asas yang biasa menjadi isu paling penting adalah penentuan nasab dan penafian nasab. Analisis trait fizikal juga adalah salah satu daripada sains yang bertitik tolak dari pewarisan genetik dari generasi sebelumnya. Pewarisan ini akan berterusan dengan kehadiran gen-gen yang tertentu dalam kromosom yang membentuk trait kepada kelahiran. Begitu juga halnya dengan pengkelasan darah kepada kumpulan $\mathrm{A}, \mathrm{B}, \mathrm{AB}$ dan $\mathrm{O}$ yang juga ditentukan dengan kehadiran gen yang terdapat dalam darah. Aplikasi bagi setiap kes yang berkaitan nasab adalah berbeza.

Jadual 3: Keseluruhan Kumpulan Darah yang Telah Ditemui Sehingga Oktober $2012^{16}$

\begin{tabular}{|c|c|c|c|}
\hline Bil. & Nama Sistem & $\begin{array}{c}\text { Simbol } \\
\text { Sistem }\end{array}$ & Nama Gen \\
\hline 1 & ABO & ABO & ABO \\
\hline 2 & MNS & MNS & GYPA, GYPB, GYPE \\
\hline 3 & P & P1 & RHD, RHCE \\
\hline 4 & Rh & RH & LEL \\
\hline 5 & Lutheran & LU & FUT3 \\
\hline 6 & Kell & KEL & DARC \\
\hline 7 & Lewis & LE & SLC14A1 \\
\hline 8 & Duffy & FY & JKC4A1 \\
\hline 9 & Kidd & DK & \\
\hline 10 & Diego & DI & \\
\hline
\end{tabular}

${ }^{13}$ Ianya disebut oleh al-Shāṭibī (1997) dalam al-Muawafaqat dan diulas oleh al-Raysuni (2006).

${ }^{14}$ Antaranya adalah galakan untuk bernikah dan keharusan untuk berpoligami (al-Sulami, 1991).

15 Antaranya adalah larangan untuk meninggalkan nikah tanpa uzur, melarang kehamilan secara total dan menggugurkan kandungan.

${ }^{16}$ Diperakui oleh HUGO Gene Nomenclature Committee, laman web rasmi: http://www.genenames.org/ 
Ahmad Syukran Baharuddin et. al. / UMRAN - International Journal of Islamic and Civilizational Studies. vol. 2, no. 2 (2015) 11-29

\begin{tabular}{|c|c|c|c|}
\hline 11 & $\mathrm{Yt}$ & YT & $A C H E$ \\
\hline 12 & $\mathrm{Xg}$ & $\mathrm{XG}$ & $X G, M I C 2$ \\
\hline 13 & Scianna & $\mathrm{SC}$ & ERMAP \\
\hline 14 & Dombrock & DO & ART4 \\
\hline 15 & Colton & $\mathrm{CO}$ & $A Q P 1$ \\
\hline 16 & Landsteiner-Wiener & LW & ICAM4 \\
\hline 17 & Chido/Rodgers & $\mathrm{CH} / \mathrm{RG}$ & $C 4 A, C 4 B$ \\
\hline 18 & $\mathrm{H}$ & $\mathrm{H}$ & FUT1 \\
\hline 19 & $\mathrm{Kx}$ & $\mathrm{XK}$ & $X K$ \\
\hline 20 & Gerbich & GE & GYPC \\
\hline 21 & Cromer & CROM & CD55 \\
\hline 22 & Knops & $\mathrm{KN}$ & CR1 \\
\hline 23 & Indian & IN & CD44 \\
\hline 24 & Ok & $\mathrm{OK}$ & $B S G$ \\
\hline 25 & Raph & RAPH & CD151 \\
\hline 26 & John Milton Hagen & JMH & SEMA7A \\
\hline 27 & I & I & GCNT2 \\
\hline 28 & Globoside & GLOB & B3GALT3 \\
\hline 29 & Gill & GIL & $A Q P 3$ \\
\hline 30 & $\begin{array}{l}\text { Rh-associated } \\
\text { glycoprotein }\end{array}$ & RHAG & $R H A G$ \\
\hline 31 & FORS & FORS & GBGT1 \\
\hline 32 & JR & JR & $A B C G 2$ \\
\hline 33 & LAN & LAN & $A B C B 6$ \\
\hline
\end{tabular}

Walaubagaimanapun terdapat pembahagian hukum berkaitan penggunaan forensik biologi untuk kes-kes tertentu. Perbincangan meliputi aspek-aspek seperti ibadat, muamalat dan munakahat. Bagi fiqh ibadat, seperti disebutkan sebelum ini tuntutan seperti berbuat baik kepada keluarga dan ibu bapa boleh dicapai sekiranya perkaitan kekeluargaan di antara anak dan ibu bapa serta saudara lain dengan menggunakan analisis dari trait fizikal dan serologi darah. Bagi kes yang berkaitan muamalat, seperti mirath, wasiat, hibah, hukum luqatah dan sedekah, penentuan kekeluargaan boleh memberi hak sebenarnya kepada hukum mirath dan wasiat, dan kelebihan berganda apabila hibah, sedekah dan hadiah diberi kepada mereka dari golongan keluarga sendiri. Adapun bagi cabang fiqh yang benar-benar terdiri dari hukum nasab seperti munakahat, pelbagai kes-kes berkaitan ahwal shakhsiyyah dapat diselesaikan dengan bantuan analisis forensik biologi ini. Namun begitu, dua kaedah yang disebutkan dalam kajian hanya mampu untuk menafikan kepastian nasab dan tidak dapat menentukan nasab secara total tanpa bantuan analisis DNA ${ }^{17}$.

Bagi trait fizikal, kajian mencadangkan supaya hadis-hadis berkaitan trait fizikal dianalisis dengan lebih mendalam dengan menggunakan hukum Pewarisan Mendel yang terdiri dari beberapa bahagian.

${ }^{17}$ Terdapat perbincangan panjang mengenai penentuan dan penafian nasab melalui cara DNA. Kesimpulan ringkas adalah pendapat menerima DNA dalam li'an adalah menerima adalah berdasarkan konteks dalil li'an adalah dalam keadaan umum dan berdasarkan maslahah semasa. Manakala pendapat yang menolak penggunaannya dalam kes li'an adalah berdasarkan kebergantungan kepada shahadah dan Iqrar serta al-Yamin yang menjadi asas li'an. 
Ahmad Syukran Baharuddin et. al. / UMRAN - International Journal of Islamic and Civilizational Studies. vol. 2, no. 2 (2015) 11-29

Kajian boleh didasarkan kepada sharah hadis berkaitan dan kesahihan hadis beserta carta pewarisan trait daripada individu yang disebut di dalam hadis berdasarkan penerangan cir-ciri trait dari matan hadis dan juga dari sharah hadis. Kesimpulan tersebut akan menyokong dengan lebih kuat bagi kaedah pensabitan nasab melalui trait fizikal yang buat masa kini disandarkan kepada konsep al-Qiyafah semata-mata sedangkan ianya boleh jadi lebih tepat dari konsep al-Qiyafah itu sendiri. Teknologi serologi darah telah berkembang dengan pesat sehinggakan sejak tarikh kumpulan darah $\mathrm{A}, \mathrm{B}, \mathrm{AB}$ dan $\mathrm{O}$ mula ditemukan, kumpulan darah telah diklasifikasikan kepada kumpulan yang lebih besar dan spesifik seperti dalam jadual berikut (Daniels, 2001; Reid, 2012; Storry et al., 2011):

Maka proses penentuan nasab boleh semakin tepat dengan bukan sahaja menggunakan sistem kumpulan darah yang utama iaitu $\mathrm{ABO}$, malah boleh ditentukan dengan pewarisan gen-gen lain dalam darah tanpa menggunakan bantuan DNA. Walaubagaimanapun, kajian lanjut perlu dibuat bagi menghubungjalin setiap antigen yang terdapat dalam darah dengan kaedah penasaban. Kajian ini mengesyorkan agar setiap sistem kumpulan bagi darah seperti disebutkan di atas dianalisis secara mendalam. Dari bidang fiqh, kajian yang disyorkan adalah dari sudut istidlal hukm bagi sains forensik untuk digunakan dalam proses pensabitan dalam kes-kes berkaitan jenayah Islam.

\subsection{KESIMPULAN}

Setelah mendapati bahawa cabang trait fizikal dan serologi dapat membantu dalam penentuan nasab, adalah menjadi suatu tanggungjawab kepada umat Islam untuk bertaamul sebaik mungkin dengan perkara-perkara yang telah disyariatkan berkaitan nasab melalui kemudahan teknologi yang telah dikurniakan melalui perantaraan akal. Analisis trait fizikal dan serologi mampu untuk memberi suatu kaedah baru dalam penghakiman kes berkaitan nasab. Kemodenan dan perkembangan teknologi dalam sains forensik hendaklah dimanfaatkan bagi kemaslahatan ummah.

\section{RUJUKAN}

'Azzām, Țāriq Șāliḥ Yūsuf. (2008). Athar Aț-Ṭibb As-Shar'ie fi ithbāt al-Huqūq wa al-Jarāim. Amman, Jordan: Dar an-Nafais.

Abu Zahrah, Muhammad. (1958). Usul al-Fiqh. Cairo: Dar al-Fikr al-'Arabi.

Ahmad Syukran Baharuddin, Aminuddin Ruskam, \& Abdul Rahim Yacob,. (2015). "The Role of Forensic Biology in Realising Maqāsid al-Shariah (The Objectives of Islamic Law).” Sains Humanika, 4(1).

Ahmad Syukran Baharuddin, Aminuddin Ruskam, \& Abdul Rahim Yacob. (2015). Prinsip Asas Sains Forensik dari Perspektif Islam: Suatu Sorotan Literatur. Sains Humanika, 4(2).

Ahmad Syukran Baharuddin, Hasna Bidin, Wan Ismail Wan Dagang, Aminuddin Ruskam, \& Abdul Rahim Yacob. (2015). Fiqh Forensics: Integration between Sciences and Islamic Law for Autopsies and Identification of Deceased. Sains Humanika, 4(2).

al-Bukhari, Muhammad ibn Ismail. (2001). Sahih al-Bukhari. Beirut: Dar Tuq al-Najat.

Alfonso R. Gennaro, Audrey Hart Nora, James J. Nora, Richard W. Stander, \& Weiss, Leon. (1935). Blakinston's Gould Medical Dictionary (fourth ed.). United States of America: Mc Graw-Hill Book Company.

al-Hafnawi, Muhammad Ibrahim. (2002). Dirasat Usuliyyah fi al-Quran al-Karim. Cairo: Maktabah wa Matba'ah al-Isha' al-Fanniyyah

al-Harayri, Ibrahim Muhammad. (1999). Al-Qawaid wa Dawabit al-Fiqhiyyah linizam al-Qadhai fi alIslam. Amman, Jordan: Dar Ammar linnashir.

al-Jassas, Ahmad bin 'Ali. (1984). Ahkam al-Qur'an. Beirut: Dar Ihya' al-Turath 'Arabiy.

al-Jurjani, Ali bin Muhammad. (1983). al-Ta'rifat. Beirut: Dar al-Kutub al-'Ilmiyyah. 
Ahmad Syukran Baharuddin et. al. / UMRAN - International Journal of Islamic and Civilizational Studies. vol. 2, no. 2 (2015) 11-29

Al-Mawsū'ah al-Fiqhiyyah al-Kuwaytiyyah. (1995). Kuwait: Ministry of Awqaf and Islamic Affairs State of Kuwait.

al-Najdi, Abdul Rahman. (1970). Manhaj 'umar al-khattab fi al-tashri': Dirasah mustaw'abah lifiqh 'umar wa tanzimatuh. Cairo, Egypt: Dar al-Fikr al-'Arabi.

al-Qarrāfi, Ahmad bin Idris bin Abd al-Rahman Shihāb al-Din. (t.t.). al-Furūq. Beirut: Ālam al-Kutub.

al-Qurtubi, Abu Abdullah Ahmad bin Muhammad Shamsuddin. (1964). Tafsir al-Qurtubi. Cairo: Dar alKutub al-Masriyyah.

al-Raysuni, Ahmad. (2006). Imam al-Shatibi's Theory of the Higher Objectives and Intents of Islamic Law. Selangor: Islamic Book Trust.

al-Shāțibī, Ibrahim Bin Musa. (1997). al-Muwāfaqāt (Abū Ubaydah Mashhūr Bin Hasan 'Ali Salmān Ed.). Mesir: Dār Ibn 'affān.

al-Sulami, Izz al-Din Abdul 'Aziz. (1991). Qawa'id al-Ahkam fi Masalih al-Anam. Cairo: Maktabah alKulliyat al-Azhariyyah.

al-Suyuti, Jalaluddin Abdul Rahman. (1993). Tafsir Al-Jalalain. Beirut: Dar al-Fikr.

al-Tabari, Muhammad bin Jarir. (2000). Jami' al-Bayan fi ta'wil al-Qur'an. Egypt: Muassasah al-Risalah.

al-Taftazani, Sa'd al-Din Mas'ud 'umar. (t.t.). Sharh al-Talwih 'ala al-Tawdih. Cairo: Maktabah Sabih.

al-Tirmizi, Abu'Isa Muhammad (1998). Sunan al-Tirmizi (Bashar 'wad Ma'ruf Ed.). Beirut: Dar al-Gharab al-Islamiy.

al-Yubi, Sa'ad Ahmad Mas'ud. (2012). Maqasid al-Shari'ah al-Islamiyyah wa 'alaqatuha bi al-Adillah alShari'ah. Saudi Arabia: Dar Ibn al-Jawzi.

al-Zayla‘i, Uthman bin Ali Fakhr al-Din‘ (1992). Tabyin al-Haqa’iq. Cairo: maktabah al-Kubra alAmiriyyah.

al-Zuhayli, Wahbah Ibn Mustafa. (t.t.). Al-Fiqh al-Islami wa Adillatuh. Damascus: Dar al-Fikr.

al-Zuhayli, Wahbah Mustafa. (1998). al-Tafsir al-Munir fi al-'Akidah wa al-Shari'ah wa al-Manhaj. Beirut: Ddar al-Fikr al-Muasir.

Amir Badshah, Muhammad Amin Mahmud. (t.t.). Taysir al-Tahrir. Beirut: Dar al-Fikr.

Auda, Jasser. (2010). Maqasid as Philosophy of Islamic Law. Selangor: Islamic Book Trust.

Bahnasi, Ahmad Fathi. (1989). Nazariyyah al-Ithbat fi al-Fiqh al-Jinaie. Beirut: Dar ash-Shuruq.

Bateson, William, \& Mendel, Gregor. (1909). Mendel's principles of heredity: Putnam's.

Beckman, Lars, Böök, Ja, \& Lander, Elvir. (1960). An evaluation of some anthropological traits used in paternity tests. Hereditas, 46(3-4), 543-569.

Cummings, Michael. (2010). Human heredity: principles and issues: Cengage Learning.

Daniels, Geoff. (2001). Blood Group Genetics. eLS.

Darden, Lindley. (1991). Theory change in science: Strategies from Mendelian genetics.

Farhud, D. D., \& Zarif Yeganeh, M. (2013). A brief history of human blood groups. Iran J Public Health, 42(1), 1-6.

Glugston, M.J. (1998). The New Penguin Dictionary of Science. London, England: The Penguin Group.

Henderson, Isabella Ferguson, \& Lawrence, Eleanor. (2008). Henderson's Dictionary of Biology: Pearson Education. 
Ahmad Syukran Baharuddin et. al. / UMRAN - International Journal of Islamic and Civilizational Studies. vol. 2, no. 2 (2015) 11-29

Hill, McGraw. (1997). McGraw-Hill Encyclopedia of Science and Technology: McGraw-Hill, New York.

Hitti, Yusuf K. (t.t.). Hitti's Englsih-Arabic Medical Dictionary. Beirut: The National Lebanese Printing Press, Beirut Lebanon.

Hoyland, Robert. (2005). Physiognomy in Islam. Jerusalem studies in Arabic and Islam(30).

Ibn al-Qayyim, Shams al-Din Muhammad. (t.t.). Al-Turuq al-Hukmiyyah. Beirut: Dar al-Kutub al'Ilmiyyah.

Ibn 'Ashur, Muhammad Tahir Bin Muhammad. (2001). Maqāsid al-Shari'ah al-Islāmiyyah. Jordan: Dār alNafāis.

Ibn Farhun, Ibrahim Bin Ali Bin Muhammad Burhanudin. (1986). Tabsirah al-Hukkam fi Usul al-Aqdiyah wa Manahij al-Ahkam. Cairo: Maktabah al-Azhari.

Ibn Kathir, Ismail bin Umar. (1999). Tafsir Ibnu Kathir: Dar al-Tayyibah li al-Nashr wa al-Tawzi'.

Ibn Majah, Muhammad Bin Yazeed al-Qazwini. (2007). English Translation of Sunan Ibn Majah. Riyadh, Kingdom of Saudi Arabia: Maktaba Dar-us-Salam.

Ibn Manzur, al-Afriqi. (1994). Lisan al-'Arab. Beirut: Dar al-Sadr.

Ibn Rajab, al-Hanbali. (1996). Fath al-Bari Sharh Sahih al-Bukhari. Cairo: Maktab al-Tahqiq Dar alHaramayn.

Ibnu Mājah, Muhammad Yazīd al-Qazwinī. (t.t.). Sunan Ibnu Mājah (Muhammad Fu'ad Abdul Bāqi Ed.). Beyrūt: Dār Ihyā' al-Kutub al-'Arabiyyah.

Kamdar, Swapnil R, \& Pandey, Astha. (2011). The Scope of Artificial Intelligence in Forensic Science. Forensic Audit, 46.

Kaplan, A. R. (1964). Genetics of Relative Toe Lengths. Acta Genet Med Gemellol (Roma), 13, 295-304.

Kiely, Terrence F. (2000). Forensic Evidence: Science and Criminal Law. New York, United States of America: CRC Press LLC.

Kirk, Paul L. (1963). The Ontogeny of Criminalistics. The Journal of Criminal Law, Criminology, and Police Science, 54(2), 3.

Landsteiner, Karl. (2013). The specificity of serological reactions: Courier Dover Publications.

Learoyd, P. (2012). The history of blood transfusion prior to the 20th century--part 2. Transfus Med, 22(6), 372-376. doi: 10.1111/j.1365-3148.2012.01189.x

M.Crim, Keith Inman, \& Rudin, Norah. (2001). Principles and Practice of Criminalistics: The profession of Forensic Science. United States of America: CRC Press.

McDonald, John H. (2011). Myths of Human Genetics: Sparky House, Baltimore, Md, USA.

McKusick, Victor A. (1998). Mendelian inheritance in man: a catalog of human genes and genetic disorders (Vol. 1): JHU Press.

Monks, SA, Leonardson, A, Zhu, H, Cundiff, P, Pietrusiak, P, Edwards, S, . . Schadt, EE. (2004). Genetic inheritance of gene expression in human cell lines. The American Journal of Human Genetics, 75(6), 1094-1105.

Muslim. (1981). Sahih Muslim bi Sharh al-Nawawi. Cairo: al-Matba'ah al-Masriyyah wa Maktabuha.

Paola A. Prada, B.S., Kenneth , \& Furton, G. (2008). Human Scent Detection: A review of Its Development and Forensic Applications. Revista de Ciencias Forenses, 1 (2), 81-87.

Pass, Ayn Embar-Seddom \& Allan D. (2009). Forensic! United States of America: Hamilton Printing Company. 
Ahmad Syukran Baharuddin et. al. / UMRAN - International Journal of Islamic and Civilizational Studies. vol. 2, no. 2 (2015) 11-29

Premuda, L. (1978). [Adriano Sturli (1873-1964) as researcher and physician]. Neue Munch Beitr Gesch Med Naturwiss Medizinhist Reihe, 7-8, 327-339.

Ramlee, Zulfakar. (1997). The Role of Qarinah (Circumstantial Evidence) In Islamic Law of Evidence: A Study of The Law In Malaysia, With Reference To The Rules And Principles of English Law. Glasgow Caledonian University, Glasgow.

Reid, M. E. (2012). ISBT Scientific Series - State of the Art Invited speakerProtein blood group systems: Berlin and beyond. ISBT Science Series, 7(1), 41-43. doi: 10.1111/j.1751-2824.2012.01544.x

Roach, Jared C, Glusman, Gustavo, Smit, Arian FA, Huff, Chad D, Hubley, Robert, Shannon, Paul T, ... Bamshad, Michael. (2010). Analysis of genetic inheritance in a family quartet by whole-genome sequencing. Science, 328(5978), 636-639.

Sayyid Qutb, Ibrahim Husin. (1993). Tafsir fi Zilal Al-Qur'an. Beirut, Lubnan: Dar Syuruq.

Shabana, A. (2012). Paternity between Law and Biology: The Reconstruction of the Islamic Law of Paternity in the Wake of DNA Testing. Zygon, 47(1), 214-239.

Sha'rawi, Muhammad Mutawalli. (1997). Tafsir As-Sha'rawi -Al-Khawatir. Cairo: Matabi' Akhbar Alyaum.

Sharma, B.R. (1989). Forensic Science in Criminal Investigation and Trials. India.

Siegel, Jay A. (2007). Forensic Science The Basics. Florida, U.S.A: CRC Press, Taylor \& Francis Group.

Storry, JR, Castilho, L, Daniels, G, Flegel, WA, Garratty, G, Francis, CL, . . Poole, J. (2011). International Society of Blood Transfusion Working Party on red cell immunogenetics and blood group terminology: Berlin report. Vox Sang, 101(1), 77-82.

Thomas, Ronald R. (2003). Detective fiction and the rise of forensic science (Vol. 26): Cambridge University Press.

Umi Kalthom Ahmad, \& Yacob, Abdul Rahim. (2003). Pengenalan Sains Forensik. Skudai: Penerbit Unvesiti Teknologi Malaysia.

Welck, M., Borg, P., \& Ellis, H. (2010). James Blundell MD Edin FRCP (1790-1877): pioneer of blood transfusion. J Med Biogr, 18(4), 194-197. doi: 10.1258/jmb.2010.010014

Weldon, Walter Frank Raphael. (1902). Mendel's laws of alternative inheritance in peas. Biometrika, 228254.

Zaydan, Abdul Karim. (1976). al-Wajiz fi Usul al-Fiqh. Muassasah al-Risalah. 